\title{
Effectiveness of Risk Management Strategies Among Deposit Money Banks in Nigeria
}

\author{
Folorunso Ilesanmi Akande ${ }^{1}$, Yimka Samson Akanfe Alalade ${ }^{2, *}$ \\ ${ }^{1}$ Bursary Division, Babcock University, Ilishan-Remo, Nigeria \\ ${ }^{2}$ Department of Banking and Finance, School of Management Sciences, Babcock University, Ilishan-Remo, Nigeria \\ Email address: \\ alalades@babcock.edu.ng (Y. S. A. Alalade), samyimka@gmail.com (Y. S. A. Alalade) \\ ${ }^{*}$ Corresponding author
}

To cite this article:

Folorunso Ilesanmi Akande, Yimka Samson Akanfe Alalade. Effectiveness of Risk Management Strategies Among Deposit Money Banks in Nigeria. Journal of Finance and Accounting. Vol. 7, No. 4, 2019, pp. 122-131. doi: 10.11648/j.jfa.20190704.13

Received: July 24, 2019; Accepted: August 19, 2019; Published: September 6, 2019

\begin{abstract}
Deposit Money Banks (DMBs) face formidable challenges in order to operate profitably. As business entities poised to maximise shareholders' wealth, they need to grow their revenue while at the same time keep their cost of funds as low as possible. The threats to achieving this come from the mandatory cash reserve ratio that restricts reasonable chunk of deposits from being invested, and their attempt to build-up deposit portfolio that tilts more towards non-interest paying demand deposit. Since the most profitable assets of the DMBs are the loans and advances, the booking of these risk assets for credit worthy customers who will meet maturing obligations as at when due, constitutes the greatest task to management. This paper is a study to determine how effective risk management practices have been among the DMBs in the Nigerian financial services sector. Survey research design was employed. The study population consisted of twenty-six (26) DMBs from which 10 were selected using purposive sampling technique. The primary data were obtained through a validated structured questionnaire. Reliability of the instrument was assessed, yielding Cronbach's Alpha coefficients for the constructs that ranged between 0.818 and 0.873 . The collected data were analysed using Relative Importance Index (RII) and Mean Score Index. Findings revealed that risk management practices were effective among the DMBs in Nigeria with RII of the 7 segments in the risk management practices above 0.80 . The board of directors' involvement came highest with 0.90 . The use of loan syndication came last with 0.82 within the risk management strategy segment. The study concluded that the active interest of the board of directors in the risk management practices contributed immensely to the effectiveness among the DMBs. The study recommends that the Central Bank of Nigeria should bring down the cash reserve ratio that restricts credit creation and causes high cost of funds, and also pay interest rate on cash reserves held by the bank.
\end{abstract}

Keywords: Relative Importance Index, Risk Management, Risk Management Practices, Liquidity Management

\section{Introduction}

The financial services industry, especially Deposit Money Banks (DMBs) act as a catalyst in the system of evolvement which serves as the willpower of economic advancement and prosperity thereby inculcating the culture of savings and funds mobilization from several small households and business firms across large area of coverage [2]. Banking Financial Institutions, especially Deposit Money Banks intermediate between the surplus and deficit sectors in the economy thereby promoting savingsinvestment process, capital formation and real growth of the economy [1]. The surplus units are the savers who have excess funds above their immediate consumption needs and can provide funds on short term to ultimate users who will not expose their savings to risky ventures that can jeopardize their funds being returned in due time. The study [27] also opined that through their intermediation duty, banks enhance formation of capital, production process and economic growth.

The research [24] highlighted two major roles performed by banks in their intermediation process as creating liquidity and transforming risk; and these twin roles impact on the larger economy by stimulating growth in the real sector. The risks DMBs are confronted with from each side of the 
balance sheet is different. From the liability side, which captures deposit taking, it involves issuing claims that are riskless and demandable at any time while lending on the other asset side of the balance sheet is more risky and involves obtaining costly information from unknown customers and extending credit on the basis of the information acquired. By this, banks create liquidity on the balance sheet by financing less liquid assets with funds from relatively more liquid liabilities [24]. For any business venture of which the DMBs are part, it is difficult to evade risk altogether because without taking some level of risk, the returns from operations will no doubt be compromised. The researcher [4] advocated avoidance of risks as much as it is feasible saying that the rational approach to risk, is at the very least to restrict exposure to it.

After the 2007-2009 global financial and economic crises, risk management in the financial services sector has never been the same again; bringing in its wake tightened regulatory requirements in the areas of capital adequacy, liquidity, leverage and demand for more disclosures in the financial reports the paper [5]. The author [15] reported that global economic meltdown triggered capital management crisis especially in market-based economies where economic activities are dominated by capital market. Following this development, according to the study [21] the analysis of stress has come up as a main supervisory instrument for financial stability, and banks have strengthened their risk lifestyles by always involving members of the board in major risk decisions. In the post-consolidation era in Nigeria, operational risks from weak internal controls and retention of fraudulent - minded staff became more pronounced causing heavy financial losses [26]. Also, attention is being drawn more closely to such non-financial risks such as damages, fines, legal and penal related costs to compliance and operational costs.

\subsection{Statement of the Problem}

Banks are exposed to high risks, both financial and nonfinancial which seriously affect their financial performance. These risks arise from the nature of their activities where they borrow on a short-term basis and lend same on a longterm basis, thereby creating a balance sheet mismatch of assets and liabilities in terms of maturity and pricing. This leads the banks to often times resort to buying costly, wholesome funds to bridge the resulting funding gaps. Secondly, despite attempts to put in place risk management structure, DMBs have not been seen to determine the optimal level of activity considering complication caused by supervisory and regulatory set-backs, and policy summersaults.

\subsection{Objectives of the Study}

The main objective of this study is to appraise the effectiveness of risk management strategies among Nigeria's Deposit Money Banks in order to deduce the effect on their financial performance. The study objectives are as follows: i) To determine the effectiveness of Risk Management Group Activities among DMBs in Nigeria.

ii) To examine the effectiveness of Identification of Risk Areas among DMBs in Nigeria.

iii) To describe the effectiveness of Assessment of Potential Risks among DMBs in Nigeria.

iv) To determine the effectiveness of Risk Response Strategies among DMBs in Nigeria.

v) To examine the effectiveness of Strategy Implementation and Allocation of Responsibility.

vi) To determine the effectiveness of Monitoring and Controls of Risk Identified.

vii) To examine the effectiveness of Review and Refining of Strategy among DMBs in Nigeria.

\subsection{Research Questions}

The research questions drawn from the listed objectives are as follows:

1. How effective has been risk management group among the DMBs in Nigeria?

2. How effective has been identification of risk areas among the DMBs in Nigeria?

3. How effective has been assessment of potential risks among the DMBs in Nigeria?

4. How effective has been risk response strategies among the DMBs in Nigeria?

5. How effective has been strategy implementation and allocation of responsibility among the DMBs in Nigeria?

6. How effective has been monitoring and controls of risks among the DMBs in Nigeria?

7. How effective has been review and refining of strategy among DMBs in Nigeria?

\section{Review of Related Literature}

The issue of risk management is critical to the survival of Deposit Money Banks. The primary purpose for undergoing this research was to examine the effectiveness of risk management practices on the financial performance of deposit money banks in Nigeria. The survey research design emphasized on the perception and expressed opinion of bank officers in the credit, relationship and risk management units of the sampled 10 DMBs. In this segment, a review of main concepts, related theories and empirics is conducted. The key related concepts under consideration include risks, risk management and risk management strategies.

\subsection{Risk}

Every organization sets goals, harnesses resources and channel activities towards achievement of the set goals which are in form of quantitative and qualitative objectives. The threats to the achievement of the goals constitute the risk. The ISO 31000 (2009)/ISO Guide 73, as reported by the study [15] defines risk as the effect of events, which may or may not happen, caused by either lack of information or 
ambiguity on the objectives. The effects on the objectives may be positive or negative. More often than not, risk has always been perceived from negative perspective. The author [19] viewed the negative perception as restrictive and misleading because uncertainty associated with the outcome could manifest as either a threat (negative) or an opportunity (positive). If an organisation is absorbed in the threats, it will lose all the opportunities that could end in good performance. This explains why the researcher [4] advocates for risk management rather than risk avoidance in order to take advantage of the opportunities. The paper [4] listed 9 generic risks inherent in the financial services sector to include, credit risk, liquidity risk, strategic risk, market risk, reputational risk, solvency risk, operational risk, counterparty risk and legal risk.

\subsection{Risk Management}

Risk management is a process by which an organisation identifies and analyses threats, examines alternatives, and accepts or mitigates those threats even before they begin to impede the activities of the organization [30]. In the CBN 2008 Supervisory Framework for Banks and other Financial Institutions in Nigeria, risk management is expressed as an independent function responsible for planning, directing and controlling the impact on the institutions of risks arising from their operations. This function may address certain areas including, identification of risks, development of measurement systems for risks, establishment of policies and procedures to manage risks, development of risk tolerance limits, monitoring positions against approved risk tolerance limits, and reporting of results of risk monitoring to senior management and the board [13]. In risk management, the objective is not to eliminate risk, but to identify and estimate the costs. Risk management in itself is meaningless, because it is a metric that influences other conditions such as profit and efficiency [6].

Banks' major role is intermediation between the funds owners and funds users by consolidating deposits from funds owners and converting them into loans for the use of funds seekers. It is in the process of performing this role that they get exposed to risks that threaten their liquidity, earnings and long term survival. The paper [3] reported that the commitment of banks to lend exposes them to unpredicted liquidity demands and the risk of not being able to adequately meet the cash needs of their customers.

Adequacy of credit risk management is pertinent to the survival of any firm in the financial industry. Basis for why many banks tend to commit substantial financial resources to this exercise. As a result, the operators seek to find means to increase opportunities even in the midst of potential risks, thereby improving efficiency and effectiveness of operations, which result to prudent management of available resources in the credit risk management process. Then, the regulatory and supervisory agencies work to ascertain regulatory compliance and advocate for greater transparency in the process as well [20].

\subsection{Theoretical Review}

On theoretical review, the theories that encapsulate this function and upon which this study is anchored are commercial loans theory, liability management theory and portfolio theory. Commercial loan theory, otherwise known as Real Bills Doctrine is the oldest theory of liquidity management which stipulates that bank lending should be on short-term since most deposits are also on short term [8]. Propounded by Adam Smith and reported in his work "The Wealth of Nations" in 1776, the theory proposes that banks should lend on short-term self-liquidating loans in view of the need to match short-term profit motive with short-term obligations of making depositors funds available when needed [11].

This theory fails to recognize long-term loan which is an engine of growth for economic development of an economy. Emphasis is on maturity profile of the assets without considering their marketability and shiftability. The theory also assumes self-liquidating loans by matching of loans and deposits without considering seasonal withdrawals and meeting credit requests that can adversely affect liquidity of the bank. The identified gaps notwithstanding, bulk of DMBs' deposit liabilities is from current and savings deposits payable on demand. At times, deposits can be terminated prematurely if the customer needs unexpected funding, although at a penal charge [22].

Liability Management Theory, developed in 1960 argued that banks can issue liabilities to meet their liquidity needs. On this premise, banks need not book self-liquidating loans and keep liquid assets since they can always approach the money market to access reserve funds whenever desired especially to pay demand depositors as well as meet fresh loan requests [17]. By this, the bank is creating more liabilities to meet funding needs through sources that may include CBN discount window, inter-bank money market, fresh issue of shares and retained earnings. However, these sources of raising liabilities, especially CBN Discount window and interbank sources are not at beck and call because it depends on the situation in the money market as well as economic environment. Too much reliance on these sources can send a wrong signal which may lead to loss of confidence by the investors. This may cause liquidity crisis. One area of focus in this study has to do with the effect of interbank sources to raise funds to finance the risk assets [31]. Liability management theory appears real in the modern day banking where banks grow their risk assets significantly while trying to do an aggressive deposit mobilisation to meet up with funding the risk asset portfolio and honouring demands of their customers for withdrawal of funds. Bank workers are being given impossible deposit mobilisation targets and are made conditions for favourable appraisal [9, 23].

Portfolio theory reveals that there is an inherent risk for every investment in that the anticipated return or earnings may not be realised at the end of the day. The theory analyses risk-return trade-off on an individual investment and those 
between selected mixes of investments. The pioneering work of modern portfolio theory has generally been credited to Harry Max Markowitz (1952) who studied the effects of asset risk, return, correlation and diversification on probable investment portfolio returns. This model assumes that an average investor is risk averse; therefore efficient diversified portfolios are those which maximise return for a given level of risk or minimize risk for a given level of return $[25,18$, 32].

Based on the literature reviewed, it was realized that not much empirical study has been conducted on the effectiveness of risk management policies among the deposit money banks in Nigeria. Therefore, the researchers considered it imperative to conduct research in the area, so as to determine how the implementation of these policies, and industry response to them influenced the financial performance of the banks.

\section{Methodology}

This is the structure in research paper that depict the activities of researcher in analyzing the related data in order to arrive at finding is a section referred to as methodology. In this section, there will be design for the study, population, sample size and sampling technique, method of data collection, validity test, administration of instrument and reliability test and method of data analysis.

\subsection{Research Design}

This study employed survey research method. Primary data were obtained by administering copies of the questionnaire to bank workers at managerial level, specifically those in the credit, relationship and risk management units. The data collected were utilized to appraise the effectiveness of risk management strategies among Nigerian Deposit Money Banks.

\subsection{Population and Sources of Data}

There were a total of twenty-six (26) Deposit Money Banks (DMBs) in Nigeria by the updated list of CBN as at $25^{\text {th }}$ May, 2016 out of which ten (10) were commercial banks with international operating licence, nine (9) were with national operating licence, two (2) were with regional license, one (1) with non-interest banking operating license, and four (4) merchant banks with national operating license.

A total of 330 copies of questionnaire were personally administered to the respondents, comprising officers of risk management group (relationship management, credit appraisal, credit administration and credit recovery) from which 312 copies were retrieved. Out of the 312 copies retrieved, 300 copies were used in this study for the analysis, representing $90.9 \%$ response rate. This is considered representative according to the study [7]. Twelve (12) copies were rejected for poor execution. The table below represents the description stated above.
Table 1. Percentage Response Rate.

\begin{tabular}{llll}
\hline Description & Frequency & Percent (\%) & Cumulative percent (\%) \\
\hline Retrieved & 312 & 94.55 & 94.55 \\
Not Retrieved & 6 & 1.81 & 96.36 \\
Rejected & 12 & 3.64 & 100 \\
Total & 330 & 100 & \\
\hline
\end{tabular}

Source: Field Survey (2017)

\subsection{Sample Size and Sampling Technique}

Ten (10) out of the twenty-six (26) DMBs that possess both national and international banking license were selected for this study, since by their deposit share, account for about $75 \%$ of all the DMBs. It is preempted that the outcome of the research based on this sample would be a representative of the industry. The selected banks were Access Bank Plc, Diamond bank Plc, First City Monument Bank Plc (FCMB), First Bank Holdings, Fidelity Bank Plc, GT Bank Plc, Stanbic IBTC Bank Plc, Union Bank of Nigeria Plc, United Bank for Africa Plc, and Zenith Bank Plc.

The sample was selected based on the ranking done by Naira-metrics, a leading financial resource company, for top 10 banks in Nigeria on the premise of deposit base and also on another ranking done by Nigerian Finder based on the parameters of international reckoning, profitability, shareholders' funds, total assets, earnings and customer deposits. In the survey study, the opinions of the respondents from the credit, relationship and risk management personnel of the selected banks were considered relevant and important to get the required data because the roles of this set of bank workers relate very closely to the area of study.

\subsection{Method of Data Collection}

The questionnaire used to obtain data was divided into two sections. Section A covered the demographic factors that helped to gain an insight into the background of different respondents in terms of gender, age, educational qualification, professional affiliation, professional status and years of experience. These demographic factors assisted to clearly bring out different views and assessment of the various respondents as they influence their perception to various issues of risk management strategies. Sections B was further divided into 7 segments, each of which posed questions on risk management strategies within the risk management cycle. This is an important aspect of the study to establish the opinions of respondents in regard to various issues on risk management. The Chartered Institute of Management Accountants [12] gave an analysis of risk management cycle elements as, risk management group, identification of risk areas, assessment of risks, risk response strategy, strategy implementation and allocation of responsibility, monitoring and controls, and review and refining strategy.

\subsection{Validity Test}

In order to establish validity of the instrument used for study, the questionnaire was drawn with professional advice 
of eminent scholars. Validity test is an attestation to whether the instrument being used to collect data measures what it is expected to and the evidence justifies it [29]. From the perspective of the research [10], validity test is the extent to which an instrument actually measures the aspects that it was supposed to measure. In order to establish face validity, expert opinions from experienced scholars was obtained as to whether the questionnaire was professionally constructed. Also, in order to ensure adequate coverage of the domain of the study, the questions were drawn on each step of the risk management strategies. In terms of construct validity, the questionnaire administered is in conformity to the subject being examined. The target respondents were skillfully selected from among experienced bank workers relating to the study for the final results to synchronise with the concept under study.

\subsection{Administration of Instrument and Reliability Test}

Reliability test reveals the consistency or the repeatability of the measure [10] which means that it can be used on an on-going basis to detect any change that may occur. For internal consistency reliability, a test-retest reliability was conducted in which case the questionnaire was repeated to the same respondents on two different occasions under the same conditions [14]. The scores from the pilot studies were consistent with the scores of the final studies as revealed in Table 2 .

The data collected from the survey were analysed using IBM Statistical Package for the Social Sciences (SPSS) software, version 21. Results from the SPSS analysis are as given in Tables 2 and 3.

Table 2. Pilot Study Response to Questionnaire.

\begin{tabular}{llll}
\hline & Frequency & Percent \% & Cumulative percent \% \\
\hline Retrieved & 60 & 92 & 92 \\
Not Retrieved & 2 & 3 & 95 \\
Rejected & 3 & 5 & 100 \\
Total & 65 & 100 & \\
\hline
\end{tabular}

Source: Field Survey (2017)

Table 3. Cronbach's Alpha Results.

\begin{tabular}{lllll}
\hline \multirow{2}{*}{ Description } & \multicolumn{2}{l}{ Pilot (Pre-field) Studies } & Post-field Studies \\
\cline { 2 - 5 } & Number of Items & Number of Items & Cronbach's Alpha \\
\hline Risk Management Group Characteristics & 7 & .761 & 7 & .873 \\
Identification of Risk Areas & 7 & .822 & 7 & .861 \\
Assessment of Risks & 5 & .74 & 5 & .865 \\
Risk Response Strategy & 6 & .785 & 6 & .845 \\
Strategy implementation and Allocation of Responsibility & 7 & .903 & 7 & .849 \\
Monitoring and Controls & 15 & .938 & 5 & .818 \\
Review and Refining of Strategy & 4 & .866 & 4 & .886 \\
\hline
\end{tabular}

Source: Field Survey (2017)

The Cronbach's Alpha value of each of the segments is greater than 0.7 which indicates that all the segments are reliable and therefore valid inferences can be drawn from the results of the analyses. To confirm internal consistency, the results of the study largely tally with the results of the pilot test as the respondents engaged in the pilot test are also included in the final test.

\subsection{Method of Data Analysis}

The paper [28] employed Relative Importance/Significance Index (RII) and Mean Index Score (MIS) in data analysis using a five-point Likert scale (1 to 5) to appraise the effectiveness of auditor independence regulations in Nigeria. The RII and MIS were used by the study [28] for ranking and assessment of twelve different auditors' independence regulations according to their effectiveness given the following formulas:

i). The relative importance / significance index, $\mathrm{RII}=\frac{\sum \mathrm{W}}{\mathrm{A} * \mathrm{~N}}$

ii). Mean Index score, MIS $==\frac{\sum \mathrm{W}}{\mathrm{N}}$,
Where ' $\mathrm{W}$ ' represents the given weight by the respondents to each regulation which ranges from 1 to 5 . A is the highest weight which is 5 in this case, while $\mathrm{N}$ represents total number of responses. The RII value had a range from 0 to 1 (i.e. $0 \leq \mathrm{RII} \leq 1$ ); the higher the value of RII, the more important/effective was the regulation considered. The weighting was determined as follows: Weight $=\sum \mathrm{W}_{i}=\sum\left(i^{*} \mathrm{n}_{i}\right)$ where $i$ is the Likert scale point (e.g. 5), and $\mathrm{n}_{i}$ is the number of respondents choosing the Likert scale point.

The same analytical methods of RII and MIS employed above were adopted for this research. The RII and MIS were used for ranking and assessment of different risk management strategies according to their effectiveness with the use of six Likert scale ( 1 to 6) which transformed into relative significance index for the factors selected using the numerical scores.

\section{Results and Discussion of Findings}

This section presents data analysis, interpretation, 
discussion of findings and summary of main findings. The data were presented using tables, frequency distributions, pictorial representations in form of bar charts and graphs. The source of data was mainly through the questionnaire describe demographic characteristics of the respondents. The essential quality and nature of the respondents are revealed by the demographic factors and this is reflected in their different views and assessment of elements in the questionnaire. The researchers were able to establish the views and perceptions of the respondents in relation to the effectiveness of risk management practices in their respective banks. In this study, the demographic factors considered are gender, age years of service, educational level of respondents, professional affiliation, professional status and years of working experience.

\subsection{Appraisal of the Effectiveness of Risk Management Strategies}

The analysis as reflected in Tables 4 to 10 show the results of computed Mean Index Score (MIS) and Relative Importance Index (RII) for the 7 different segments of risk management practices among 10 selected DMBs in Nigeria. The RIIs for all the variables are above 0.8 indicating that risk management practices are very effective being close to 1.0 score.

In Table 4, the RII ranking shows that the Board of Directors interest in risk management strategy (5.42) topped the scale among the elements within the Risk Management Group (RMG), followed by the composition of the RMG (5.24). This shows that risk management is taken serious at the topmost level of governance among the DMBs and is reflected in the composition of the control groups within the hierarchy.

Table 4. Risk Management Group.

\begin{tabular}{|c|c|c|c|c|c|c|c|c|c|c|c|}
\hline Description & $\mathbf{N}$ & 6 & 5 & 4 & 3 & 2 & 1 & Weight & MIS & RII & Rank \\
\hline The Board of directors' interest in risk management strategy & 300 & 169 & 97 & 28 & 4 & 2 & 0 & 1627 & 5.42 & 0.9039 & 1 \\
\hline The composition of the risk management group & 300 & 118 & 143 & 33 & 5 & 1 & 0 & 1572 & 5.24 & 0.8733 & 2 \\
\hline The schedule meetings of the risk management committee & 300 & 121 & 134 & 41 & 3 & 1 & 0 & 1571 & 5.24 & 0.8728 & 3 \\
\hline $\begin{array}{l}\text { The coordination of the risk management group in the } \\
\text { management of risks }\end{array}$ & 300 & 115 & 140 & 38 & 2 & 2 & 3 & 1555 & 5.18 & 0.8639 & 5 \\
\hline $\begin{array}{l}\text { The risk management group in conducting review of } \\
\text { systems and procedures to identify and assess risks. }\end{array}$ & 300 & 117 & 142 & 35 & 3 & 3 & 0 & 1567 & 5.22 & 0.8706 & 4 \\
\hline The process of ensuring reduction of bad debts & 300 & 93 & 138 & 57 & 11 & 1 & 0 & 1511 & 5.04 & 0.8394 & 7 \\
\hline The process of enhancing corporate income generation & 300 & 120 & 126 & 42 & 12 & 0 & 0 & 1554 & 5.18 & 0.8633 & 6 \\
\hline
\end{tabular}

Source: Researcher's Computation, 2017

Table 5 below shows the results of the computed MIS and RII under the Identification of Risk Areas (IRA) segment (5.2). Topping the ranking is the Use of Process Mapping in Identifying Critical Risk Areas. This means that the work flows and functions are well connected in such a way that risk management practice is embedded. Second in the ranking is the use of brainstorming session between management, line managers and operations staff to identify critical risk areas. This participatory decision making process is an effective tool to achieving organizational effectiveness. At the bottom of the ranking (number 7) is the use of questionnaires to identify critical risk areas.

Table 5. Identification of Risk Areas.

\begin{tabular}{|c|c|c|c|c|c|c|c|c|c|c|c|}
\hline Description & $\mathbf{N}$ & 6 & 5 & 4 & 3 & 2 & 1 & Weight & MIS & RII & Rank \\
\hline The use of interviews in identifying critical risk areas & 300 & 85 & 136 & 64 & 8 & 5 & 2 & 1482 & 4.94 & 0.8233 & 6 \\
\hline $\begin{array}{l}\text { The use of workshops and seminars in identifying critical risk } \\
\text { areas }\end{array}$ & 300 & 88 & 136 & 61 & 10 & 4 & 1 & 1491 & 4.97 & 0.8283 & 5 \\
\hline $\begin{array}{l}\text { Brainstorming sessions between management, line managers } \\
\text { and operations staff in identification of critical risk areas }\end{array}$ & 300 & 103 & 139 & 41 & 11 & 5 & 1 & 1521 & 5.07 & 0.8450 & 2 \\
\hline The use of process mapping in identifying critical risk areas & 300 & 104 & 155 & 39 & 2 & 0 & 0 & 1561 & 5.2 & 0.8672 & 1 \\
\hline $\begin{array}{l}\text { The process of benchmarking the critical risk areas in my bank } \\
\text { with other comparable banks }\end{array}$ & 300 & 86 & 154 & 49 & 8 & 3 & 0 & 1512 & 5.04 & 0.8400 & 3 \\
\hline The use of questionnaires in identifying critical risk areas & 300 & 72 & 126 & 67 & 29 & 5 & 1 & 1428 & 4.76 & 0.7933 & 7 \\
\hline $\begin{array}{l}\text { The process of communicating to employees the risk prone } \\
\text { areas }\end{array}$ & 300 & 94 & 137 & 54 & 13 & 1 & 1 & 1507 & 5.02 & 0.8372 & 4 \\
\hline
\end{tabular}

Source: Researcher's Computation, 2017

Among the elements within the Assessment of Risks segment, the Training of Managers on Risk Assessment to ensure risk assessment is built into their working practices topped the ranking as shown in Table 6 . This is followed by Impact analysis on the viability, reputation and performance of the bank in view of political and commercial sensitivities. This underscores the importance of continuous training of personnel to improve their efficiency at work which ultimately leads to improved performance of the entire firm. 
Table 6. Assessment of Risks.

\begin{tabular}{|c|c|c|c|c|c|c|c|c|c|c|c|}
\hline Description & $\mathbf{N}$ & 6 & 5 & 4 & 3 & 2 & 1 & Weight & MIS & RII & Rank \\
\hline $\begin{array}{l}\text { Training of managers on risk assessment to ensure risk } \\
\text { assessment is built into their working practices }\end{array}$ & 300 & 123 & 126 & 39 & 8 & 0 & 4 & 1552 & 5.17 & 0.8622 & 1 \\
\hline $\begin{array}{l}\text { Impact analysis on the viability, reputation and performance } \\
\text { of the bank in view of political and commercial sensitivities }\end{array}$ & 300 & 105 & 151 & 34 & 4 & 4 & 2 & 1543 & 5.14 & 0.8572 & 2 \\
\hline Assessment of risks on the basis of likelihood of occurring & 300 & 93 & 157 & 45 & 0 & 2 & 3 & 1530 & 5.1 & 0.8500 & 4 \\
\hline Assessment of risks on the basis of magnitude of the impact & 300 & 84 & 160 & 48 & 8 & 0 & 0 & 1520 & 5.07 & 0.8444 & 5 \\
\hline $\begin{array}{l}\text { Keeping a comprehensive list of individual risks and } \\
\text { maintaining a ready plan of action to address every risk }\end{array}$ & 300 & 106 & 133 & 55 & 2 & 1 & 3 & 1532 & 5.11 & 0.8511 & 3 \\
\hline
\end{tabular}

Source: Researcher's Computation, 2017

Table 7 reflects the results of the computed MIS and RII for the elements listed under Risk Management Strategy (RRS). Topping the raking is The Process of Avoiding Certain Product Lines and Markets that are considered too risky. This is an indication that the DMBs have bounds beyond which they do not cross when it comes to booking of risk assets despite the fact that they are the most profitable part of their assets portfolio. Booking of loans is not a freefor-all thing that is recklessly done. It is therefore not surprising that next in rank under this segment is keeping a
Comprehensive Insurance Policy on Collateral security pledged for risk assets. This is to ensure that there is a realizable fallback asset in the event of failed performance.

The result shows that the use of loan syndication as a risk transfer strategy came last in the ranking. This age-long practice is being gradually abandoned. That explains why the economy is not experiencing high value syndicated facilities which is what is mostly required in infrastructural development due to huge amount involved, which the balance sheet of an individual bank may not be able to carry.

Table 7. Risk Response Strategy.

\begin{tabular}{|c|c|c|c|c|c|c|c|c|c|c|c|}
\hline Description & $\mathbf{N}$ & 6 & 5 & 4 & 3 & 2 & 1 & Weight & MIS & RII & Rank \\
\hline $\begin{array}{l}\text { The process of avoiding certain product lines and markets } \\
\text { that are considered too risky }\end{array}$ & 300 & 135 & 117 & 44 & 4 & 0 & 0 & 1583 & 5.28 & 0.8794 & 1 \\
\hline The controls and procedures put in place to minimize risks & 300 & 87 & 163 & 47 & 1 & 1 & 1 & 1531 & 5.1 & 0.8506 & 3 \\
\hline $\begin{array}{l}\text { Comprehensive insurance policy on collateral security } \\
\text { pledged for risk assets }\end{array}$ & 300 & 134 & 133 & 28 & 5 & 0 & 0 & 1532 & 5.11 & 0.8511 & 2 \\
\hline The response of the bank to environmental changes & 300 & 92 & 140 & 58 & 8 & 2 & 0 & 1512 & 5.04 & 0.84 & 4 \\
\hline $\begin{array}{l}\text { The use of marketable security pledged (equitable or } \\
\text { legal) as a risk response strategy }\end{array}$ & 300 & 102 & 140 & 51 & 4 & 2 & 1 & 1500 & 5 & 0.8333 & 5 \\
\hline The use of loan syndication as a risk transfer strategy & 300 & 77 & 142 & 70 & 10 & 1 & 0 & 1484 & 4.95 & 0.8244 & 6 \\
\hline
\end{tabular}

Source: Researcher's Computation, 2017

Making risk management as a key part of the organization's decision making process had the highest ranking among other items in the strategic implementation and allocation of responsibility scale (Table 8). This strategic focus definitely has contributed to the effectiveness of risk management practices among the DMBs in the country.
Closely following this is a well-structured due process of loan approval, perfection of securities and disbursement procedures. Equally important and ranking as number 3 is the spreading of risk assets among various sectors of the economy. This diversification process helps the DMBs to minimise the chance of loss and ensure financial stability.

Table 8. Strategy Implementation and Allocation of Responsibility.

\begin{tabular}{|c|c|c|c|c|c|c|c|c|c|c|c|}
\hline Description & $\mathbf{N}$ & 6 & 5 & 4 & 3 & 2 & 1 & Weight & MIS & RII & Rank \\
\hline $\begin{array}{l}\text { The process of allocating responsibility among officers in the } \\
\text { bank }\end{array}$ & 300 & 105 & 145 & 39 & 10 & 0 & 1 & 1542 & 5.14 & 0.8567 & 5 \\
\hline $\begin{array}{l}\text { The process of communicating of strategy to responsible officers } \\
\text { in the bank }\end{array}$ & 300 & 97 & 156 & 39 & 7 & 1 & 0 & 1541 & 5.13 & 0.8561 & 6 \\
\hline $\begin{array}{l}\text { The process of obtaining cooperation of the entire workforce on } \\
\text { risk management strategy }\end{array}$ & 300 & 106 & 148 & 38 & 7 & 1 & 0 & 1551 & 5.17 & 0.8617 & 4 \\
\hline $\begin{array}{l}\text { Making risk management as a key part of the organisation's } \\
\text { decision making process }\end{array}$ & 300 & 121 & 140 & 30 & 6 & 0 & 3 & 1567 & 5.22 & 0.8706 & 1 \\
\hline $\begin{array}{l}\text { Placing more emphasis on retail deposits than tenured, interbank } \\
\text { and public sector deposits }\end{array}$ & 300 & 100 & 137 & 53 & 8 & 1 & 1 & 1524 & 5.08 & 0.8467 & 7 \\
\hline Spreading of Risk assets among various sectors of the economy & 300 & 111 & 142 & 41 & 4 & 1 & 1 & 1555 & 5.18 & 0.8639 & 3 \\
\hline Approval of facilities, perfection of collaterals and disbursement. & 300 & 108 & 142 & 48 & 2 & 0 & 0 & 1556 & 5.19 & 0.8644 & 2 \\
\hline
\end{tabular}

Source: Researcher's Computation, 2017

Table 9 reveals the ranking results of the survey under monitoring and controls. Topmost effective strategy is 
monitoring of red flags from the operations of borrowed customer with RII value of 0.8761 . This underscores the importance of credit administration where after disbursement, credit performance of great essence. Where monitoring is weak, credit customers may divert funds meant for loan repayment to other uses. Banks have therefore developed a method of notifying credit customer of meeting obligations ahead of time. Where repayment is delayed, the bank is able to review the situation to determine whether the default is deliberate or as a result of unforeseeable economic situation which may require expert advice or even some additional funding or restructuring to help the customer out of the woods. However, monitoring and controls are very effective among the DMBs going by the RII values of all the elements in this category having not less than 0.80 .

Almost of equal value with the element on top are the elements that ranked $2^{\text {nd }}$ and $3^{\text {rd }}$ with RII values of 0.8733 and 0.8678. Making people responsible and accountable in the risk management process which came second has become an effective strategy in monitoring and controls. Bank staff can own the outcome of the process and because this has impact on their integrity and career, they are therefore likely to take informed decisions not based on sentiments. The $3^{\text {rd }}$ factor in the ranking is maintenance of limit on specialised credits. Sticking to approved limits ensures that credit discipline from both the lender and borrower and this helps parties to manage their cash flows better.

Table 9. Monitoring and Controls.

\begin{tabular}{|c|c|c|c|c|c|c|c|c|c|c|c|}
\hline Description & $\mathbf{N}$ & 6 & 5 & 4 & 3 & 2 & 1 & Weight & MIS & RII & Rank \\
\hline $\begin{array}{l}\text { The process of defining key areas of responsibility that gives room } \\
\text { for accountability }\end{array}$ & 300 & 122 & 136 & 36 & 4 & 2 & 0 & 1572 & 5.24 & 0.8733 & 2 \\
\hline $\begin{array}{l}\text { The process of enforcing clear lines of authority and strict } \\
\text { adherence to approval limits }\end{array}$ & 300 & 109 & 149 & 37 & 3 & 1 & 1 & 1559 & 5.20 & 0.8661 & 4 \\
\hline $\begin{array}{l}\text { The process of applying penalty and sanctions on staff for costly } \\
\text { negligent actions to the bank }\end{array}$ & 300 & 104 & 137 & 46 & 11 & 2 & 0 & 1530 & 5.10 & 0.8500 & 13 \\
\hline Regular internal audit processes of credit activities and portfolio & 300 & 114 & 130 & 45 & 9 & 2 & 0 & 1545 & 5.15 & 0.8583 & 9 \\
\hline $\begin{array}{l}\text { Prompt assessment and compliance with regulatory policies, } \\
\text { guidelines and circulars }\end{array}$ & 300 & 106 & 146 & 39 & 8 & 1 & 0 & 1548 & 5.16 & 0.8600 & 8 \\
\hline $\begin{array}{l}\text { Monitoring of red flags from the operations of the borrowed } \\
\text { customer. }\end{array}$ & 300 & 125 & 136 & 35 & 1 & 1 & 2 & 1577 & 5.26 & 0.8761 & 1 \\
\hline Monitoring overtrading of customer through excessive borrowing & 300 & 89 & 152 & 52 & 5 & 2 & 0 & 1521 & 5.07 & 0.8450 & 14 \\
\hline Maintaining limit on single obligor limit & 300 & 97 & 151 & 50 & 2 & 0 & 0 & 1543 & 5.14 & 0.8572 & 10 \\
\hline $\begin{array}{l}\text { Maintaining limit on exposure to directors and significant } \\
\text { shareholders }\end{array}$ & 300 & 116 & 132 & 46 & 5 & 1 & 0 & 1557 & 5.19 & 0.8650 & 5 \\
\hline Disclosure of insider-related credits in the financial statements & 300 & 97 & 130 & 64 & 8 & 0 & 1 & 1513 & 5.04 & 0.8406 & 15 \\
\hline Maintaining limit on contingent liabilities & 300 & 105 & 136 & 48 & 9 & 2 & 0 & 1533 & 5.11 & 0.8517 & 12 \\
\hline Maintaining limit on specialised credits & 300 & 119 & 129 & 47 & 5 & 0 & 0 & 1562 & 5.21 & 0.8678 & 3 \\
\hline Compliance with guidelines on margin lending & 300 & 114 & 131 & 51 & 4 & 0 & 0 & 1555 & 5.18 & 0.8639 & 6 \\
\hline
\end{tabular}

Source: Researcher's Computation, 2017

It is important to note from Table 9 that the variable with the lowest rank should be of great concern to credit administrators. Insider related credits has contributed to bank distress in the country. This is evident from many celebrated court cases involving Chief Executive Officers (CEOs) of many banks with Economic and Financial Crimes Commission (EFCC) where credits were extended to themselves and their cronies. The yearly re-assessment and report came top with RII of 0.8806 in the ranking under
Review and Refining of Strategy (Table 10). All the elements under this strategy have RII above 0.8 indicating an effective strategy among the DMBs. Coming second in the ranks with RII of 0.8783 is periodic review and update of credit and operations manuals in line with new realities. The economic environment is dynamic which requires that the parameters of assessment be reviewed to ensure that risk management decisions are in tune with current realities and the bank is not led into jeopardy.

Table 10. Review and Refining of Strategy.

\begin{tabular}{|c|c|c|c|c|c|c|c|c|c|c|c|}
\hline Description & $\mathbf{N}$ & 6 & 5 & 4 & 3 & 2 & 1 & Weight & MIS & RII & Rank \\
\hline $\begin{array}{l}\text { Periodic review and update of credit and operations manuals in line } \\
\text { with new realities }\end{array}$ & 300 & 122 & 144 & 29 & 4 & 0 & 1 & 1581 & 5.27 & 0.8783 & 2 \\
\hline Periodic assessment of controls to identify gaps & 300 & 117 & 143 & 35 & 4 & 1 & 0 & 1571 & 5.24 & 0.8728 & 4 \\
\hline Yearly re-assessment of risk and reporting to management committee & 300 & 122 & 143 & 33 & 2 & 0 & 0 & 1585 & 5.28 & 0.8806 & 1 \\
\hline Periodic review of risk profile within the bank & 300 & 122 & 132 & 43 & 2 & 1 & 0 & 1572 & 5.24 & 0.8733 & 3 \\
\hline
\end{tabular}




\subsection{Discussion of Findings}

The study discovered that there is a significant relationship between Risk Management and Financial Performance of Deposit Money Banks in Nigeria. Banks are among the top league of companies that report super profits year after year in Nigeria. Bulk of the declared profits comes from risk assets which are booked from funds mobilised as deposits whose repayment timelines are generally shorter than that of the loans booked. There is therefore an intricate interplay of risk and liquidity management, the effectiveness of which will determine short term solvency and long term stability of the banks.

The results of the Relative Importance Index (RII) computed for all the variables were above 0.8 , an indication that risk management practices are very effective among the DMBs because the scores are close to 1 . Within the Risk Management Group, the Board of Directors Interest in risk management, and the composition of the Risk Management Group came first and second in the rankings respectively. This shows high level attention to risk management at the topmost level of governance. The data from the survey exercise which revealed the difference in perception of the respondents were analyzed with Independent - Samples T test using SPPS 15.0.131.

From all the 51 listed elements in the 7 group of risk management strategies, the element that topped the list in terms of Relative Importance Index is the Board of directors' interest in risk management strategy with RII of 0.9039 . This shows the importance that is attached to risk management at the highest level of governance and underscores the final outcome of the study that risk management practices is highly effective among the DMBs. Another factor that brought effective risk management practices is the process of making risk management process a key part of decision making. In addition, there has been constant monitoring of booked risk assets by discerning red flags from the businesses of borrowing customers.

The use of loan syndication came last in the ranking segment on risk transfer strategy. This is inimical to economic growth and development as DMBs now focus more on quick-earning, short-tenured facilities, the volume of which is not enough to upturn the economy to speedy progress. The greatest challenge facing the country at the moment aside from corruption is infrastructural decay especially in the areas of power supply and road network. These areas are capital intensive and will require a pool of funds from a syndicate of banks to finance these sectors.

\subsection{Conclusion}

Risk management practices among the DMBs in Nigeria have been very effective. The Board of Directors are deeply involved in risk management and because of this the industry has become reasonably free of bank failures in recent times. One of the reasons that has probably contributed to this is the effective regulatory functions by the $\mathrm{CBN}$ which monitors closely the operations of the DMBs and takes pre-emptive step by conducting stress test when there are danger signals to avert. The regulator does not waste time in sacking the board of directors of any erring bank when the signals from stress test are ominous. The banking industry remains the most regulated in the country in view of the financial and economic crises that can befall the country in case of banks failure as witnessed in the global crisis of 2008 to 2009 . Therefore the effectiveness of risk management strategies among Deposit Money Banks in Nigeria is pertinent to the survival of the industry and other sectors of the economy.

\subsection{Recommendations}

Following findings from and conclusions drawn on this study, the following recommendations are presented which are considered useful to bank management, investors and policy formulators:

The least ranked element under the risk management practices analysis is the use of questionnaire to identify other critical risk areas (RII $=0.7933)$, followed by the use of interviews in identifying critical risk areas (RII $=0.8233$ ). DMBs should use the surveying method to seek opinion of members of staff across the entire workforce as well as that of the customers to identify more critical risk areas. It is not enough to concentrate on internal publics alone but throwing it open to external clientele will draw from the experience and expertise of many people to strengthen risk management structure.

It is also recommended that DMBs should collaborate and bring back the age-long practice of syndicated facilities in order to finance infrastructural development. This is because most of the DMBs cannot muster enough capital for this kind of high-tech financing.

The DMBs should periodically conduct surveys among their various categories of customers to have a feel of their risk areas in the banking relationship. This will assist the DMBs to strengthen their risk infrastructure from time to time. In the modern day banking new innovations come up especially in the area of technology and processes. It is therefore important to block any gap that may cause financial injury to the parties.

\section{References}

[1] Adegbite, E. O. (2007). Essentials of Money and Banking ( $1^{\text {st }}$ Ed.) Lagos, Nigeria: Chumek Ventures.

[2] Ajibola, J. O. \& Olowolaju, P. S. (2017). The Influence of Assets Management on Financial Performance of Some Selected Nigeria Deposit Money Bank. Account and Financial Management Journal, 2 (4), 652-674.

[3] Aliyu, S. B. (2013). An Assessment of Factors Affecting Banks' Risk Exposure in North Central Nigeria. European Journal of Business and Management, 5 (30), 2-6.

[4] Audu, I. (2014). Risk Management in Financial Services Industry (10 ${ }^{\text {th }}$ Ed.). Understanding Monetary Policy Series, 40. Abuja, CBN. 
[5] Ashby, S. (2010). The 2007-09 Financial Crisis: Learning the Risk Management Lessons. Retrieved from https://www.nottingham.ac.uk/business/businesscentres/crbfs/ documents/researchreports/paper65.pdf

[6] Awojobi, O., Amel, R. \& Norouzi, S. (2011). Analysing Risk Management in Banks: Evidence of Bank Efficiency and Macroeconomic Impact. Eastern Mediterranean University. Retrieved from https://mpra.ub.unimuenchen.de/33590/1/MPRA_paper_33590.pdf

[7] Babbie, E. R. (1998). The Practice of Social Research, $\left(8^{\text {th }}\right.$ Ed.). Belmont: Wadsworth Publishing.

[8] Bassey, F. A., Tobi, E. G., Bassey, I. F. \& Ekwere, R. E. (2016). Liquidity Management and the Performance of Banks in Nigeria. International Journal of Academic Research in Accounting, Finance and Management Sciences, 6 (1), 41-48.

[9] Brom, K. (2009). Asset and Liability Management for Deposit-Taking Microfinance Institutions. Washington, D. C.: CGAP, No. 55, June. Retrieved from https://www.cgap.org/sites/default/files/CGAP-Focus-NoteAsset-and-Liability-Management-for-Deposit-TakingMicrofinance-Institutions-Jun-2009.pdf

[10] Bryman, A. \& Bell, E. (2011). Business Research Methods (3 ${ }^{\text {rd }}$ Ed.). UK: Oxford University Press.

[11] Carlson, M., Duygan-Bump, B. \& Nelson, W. (2015). Why Do We Need Both Liquidity Regulations and a Lender of Last Resort? A Perspective from Federal Reserve Lending during the 2007-09 U.S. Financial Crisis. Finance and Economics Discussion Series, Divisions of Research \& Statistics and Monetary Affairs, Federal Reserve Board, Washington, D. C. Retrieved from https://www.federalreserve.gov/econresdata/feds/2015/files/20 15011pap.pdf

[12] Chartered Institute of Management Accountants (2008). Fraud Risk Management: A Guide to Good Practice, by CIMA; UK.

[13] CBN (2008). Supervisory Framework for Banks and Other Financial Institutions in Nigeria. Retrieved from https://www.cbn.gov.ng/OUT/2010/CIRCULARS/BSD/CBN $\% 20 R B S \% 20 F R A M E W O R K-$ KIM\%20FINAL\%2012\%202010.PDF

[14] Deniz, M. S. \& Alsaffar, A. A. (2013). Assessing the Validity and Reliability of a Questionnaire on Dietary Fibre-related Knowledge in a Turkish Student Population. International Centre for Diarrhoeal Disease Research. Bangladesh, (4) 497 503.

[15] Dugguh, S. I. \& Diggi, J. (2015). Risk Management Strategies in Financial Institutions in Nigeria: The Experience of Commercial Banks. International Journal of Research in Business Studies and Management, 2 (6), 66-73.

[16] Ejoh, N. O., Okpa, I. B. \& Egbe, A. A. (2014). The Impact of Credit and Liquidity Risk Management on the Profitability of Deposit Money Banks in Nigeria. International Journal of Economics, Commerce and Management: Vol. II, Issue 9, September.

[17] Elliott, D. J. (2014). Bank Liquidity Requirements: An Introduction and Overview. Published by The Brookings Institution June 23. Retrieved from https://www.brookings.edu/wpcontent/uploads/2016/06/23_bank_liquidity_requirements_intr o_overview_elliott.pdf
[18] Elbannan, M. A. (2015). The Capital Asset Pricing Model: An Overview of the Theory. International Journal of Economics and Finance; Vol. 7, No. 1.

[19] Fadun, O. S. (2013). Risk Management and Risk Management Failure: Lessons for Business Enterprises. International Journal of Academic Research in Business and Social Sciences, Vol. 3, No. 2, February.

[20] Franklin, C. M. \& Schmidt, J. R. (2016). Efficiency and Transparency in Credit Risk Management. Retrieved from https://www.crowe.com/insights/bankingperformance/efficiency-and-transparency-in-credit-riskmanagement

[21] Harle, P., Havas, A., Kremer, A., Rona, D. \& Samandari, H. (2015). The Future of Bank Risk Management. McKinsey Working Papers on Risk; McKinsey \& Company.

[22] Ibe, S. O. (2013). The Impact of Liquidity Management on the Profitability of Banks in Nigeria. Journal of Finance and Bank Management: 1 (1); June, pp. 37-48.

[23] Mishkin, F. S. (2007). The Economics of Money, Banking and Financial Markets, 8th edition. Appendix 1 to Chapter 9, "Duration Gap Analysis." New York: Addison Wesley.

[24] Ndukwe, O. C. (2013). Banking System Liquidity. Understanding Monetary Policy series, 34; Monetary Policy Department, Abuja. CBN.

[25] Omisore, I., Yusuf, M. \& Nwufo, C. I. (2012). The Modern Portfolio Theory as an Investment Decision Tool. Journal of Accounting and Taxation, Vol. 4 (2), pp. 19-28, March.

[26] Owojori, A. A., Akintoye, I. R., \& Adidu, F. A. (2011). The Challenge of Risk Management in Nigerian Banks in the PostConsolidation Era. Journal of Accounting and Taxation, 3 (2), 23-31.

[27] Owolabi, S. A. \& Ogunlalu A. E. (2013). Banking industry consolidation and financial performance of selected quoted banks in Nigeria. Journal of Applied Finance and Banking, 3 (3), 219-238.

[28] Salawu, M. K. (2017). An Appraisal of the Effectiveness of Auditor Independence Regulations in Nigeria. African Researcher Review: An International Multi-Disciplinary Journal, 11 (2), S/NO 46, April.

[29] Sekaran, U. (2003). Research Methods for Business: A skillbuilding approach ( $4^{\text {th }}$ Ed.). New York: John Wiley \& Sons, Inc.

[30] Staton, P. S. (2012). The Impact of Credit Risk Management on Financial Performance of Commercial Banks in Nepal. International Journal of Arts and Commerce, 1 (5), 9-15.

[31] Umasom, P. (2018). Money Market Instruments and Nigeria Inflation Rate: A Time Series Study. Asian Finance \& Banking Review; Vol. 2, No. 2.

[32] Zhang, Y. (2016). Methods to Minimize the Risks in International Portfolio Investing. Unpublished Bachelor's Thesis Degree Programme in International Business; HaagaHelia University of Applied Sciences. Retrieved from https://www.theseus.fi/bitstream/handle/10024/122229/Zhang -Ying.pdf?sequence=1 